\title{
Fuzzy Logic Control Automation for Traffic Signalization System
}

\author{
${\text { Ecem } \text { Acar }^{1 *} \text {, Sevilay Kırc1 Serenbay }}^{2}$ \\ 1* Harran University, Faculty of Arts and Science, Departmant of Mathematic, Şanlıurfa, Turkey, (ORCID: 0000-0002-2517-5849), karakusecem@harran.edu.tr \\ ${ }^{2}$ Harran University, Faculty of Arts and Science, Departmant of Mathematic, Şanliurfa, Turkey, (ORCID: 0000-0001-5819-9997), sevilaykirci@gmail.com
}

(1st International Conference on Applied Engineering and Natural Sciences ICAENS 2021, November 1-3, 2021)

(DOI: 10.31590/ejosat.1012557)

ATIF/REFERENCE: Acar, E. \& Kırc1 Serenbay, S. (2021). Fuzzy Logic Control Automation for Traffic Signalization System. European Journal of Science and Technology, (28), 1044-1047.

\begin{abstract}
Automation systems are important structure that provides needs in many sectors such as manufacturing, construction, electricity, recycling, energy, electronics and informatics. Recently the automation systems have become larger and more complex. Situations that are completely specific and certain can be easy to resolve. However, the solution of problems that contain uncertainty and can't be fully defined is relatively difficult. Therefore, conventional logic is not sufficient because of its strictly defined boundaries. Fuzzy Logic Control is provided by executing the control algorithm in many areas at industrial automation. In this paper, we developed the Fuzzy Logic Control algorithm for a low-level PLC without Fuzzy Logic Control Module. Then, we realized PLC based fuzzy logic control for intersection traffic signaling control.
\end{abstract}

Keywords: Fuzzy logic, Automation, PLC.

\section{Trafik Sinyalizasyon Sistemi için Bulanık Mantık Kontrol Otomasyonu}

Öz

Otomasyon sistemleri imalat, inşaat, elektrik, geri dönüşüm, enerji, elektronik ve bilişim gibi birçok sektörde ihtiyaçları karşılayan önemli yapılardır. Son zamanlarda otomasyon sistemleri daha büyük ve daha karmaşık hale gelmiştir. Tamamen spesifik ve kesin olan durumların çözülmesi kolay olabilir. Ancak belirsizlik içeren ve tam olarak tanımlanamayan problemlerin çözümü nispeten zordur. Bu nedenle, kesin olarak tanımlanmış sınırları nedeniyle geleneksel mantık yeterli değildir. Bulanık Mantık Kontrol, endüstriyel otomasyonda birçok alanda kontrol algoritması çalıştırılarak sağlanmaktadır. Bu makalede, Bulanık Mantık Kontrol Modülü olmayan düşük seviyeli bir PLC için Bulanık Mantık Kontrol algoritmasını geliştirdik. Daha sonra kavşak trafik sinyalizasyon kontrolü için PLC tabanlı bulanık mantık kontrolünü gerçekleştirdik.

Anahtar Kelimeler: Bulanık mantık, Otomasyon, PLC.

\footnotetext{
* Corresponding Author: karakusecem@harran.edu.tr
} 


\section{Introduction}

Automation is the manufacturing systems produced to reduce manpower and ensure that the work is done by machines. Enterprice Resource Planning/ Meaninge- ment Enterprice System (ERP/MES), Supervisory Control And Data Aquasition (SCADA), Distuributed Control Ssystem (DCS), Programmable Logic Controller (PLC), Remote Terminal Unite (RTU), Human Machine Interface (HMI) and sensors are the basis components of the automation systems. PLC (Programmable Logic Controller) is a microprocessor-based device that processes the information it receives from the sensors according to the program given to it and transfers it to the work elements. It is an automation device that is used in the production departments of factories or in the control processes of working machines, can be programmed and can perform automatic work.

PLCs used today have reached a level that cannot be compared with their initial state in terms of features such as the number of inputs and outputs, program memory, and processing capability. The number of inputs and outputs and the processing capability have improved greatly in terms of memory. Thus, it has become the most important element in system automation. It is among the materials preferred in automation due to its unique programming technique, easy identification of its inputs and outputs, having a processor, counter, timer, clock and many more advantages. Recently the automation systems have become larger and more complex. Situations that are completely specific and certain can be easy to resolve. However, the solution of problems that contain uncertainty and cannot be fully defined is relatively difficult. Therefore, conventional logic is not sufficient because of its strictly defined boundaries.

The classical set theory is based on an element is either a member or not a member of a set. Since fuzzy set theory accepts partial memberships in contrast to the classical set theory; while fuzzy set theory allows ambiguous answers, responses of questions in the classical set can be called crisp or classic, like "yes" or "no". Fuzzy logic uses approximate thinking instead of thinking based on precise values and information is in the form of linguistic expressions. Words like young, tall, hot or high are fuzzy. There is no single quantitative value which defines the term tall. For some situation, $50 \mathrm{~cm}$ is tall, and for other situation, $90 \mathrm{~cm}$ is tall. The concept tall has no clean boundary.

\section{Material and Method}

The first idea of fuzzy logic was introduced by Zadeh in 1965 [1]. He defined the fuzzy set theory which consists of sets with indefinite boundaries. In 1974 [2], Mamdani presented the application of fuzzy logic with the control of the steam engine. In 1976 [3], an industrial application to control cement kilns was developed in Denmark and in 1982, this system began to management. Fuzzy logic implementations are used in many areas such as electronic control systems, automotive industry braking systems, traffic control, home electronics, banks and academic education. Therefore, it has been one of the most important property of fuzzy logic that it allows ambiguous concepts can be expressed as mathematical and many researchers have shown interest in this field ([5]-[10]). Fuzzy logic control system general structure is as follows.

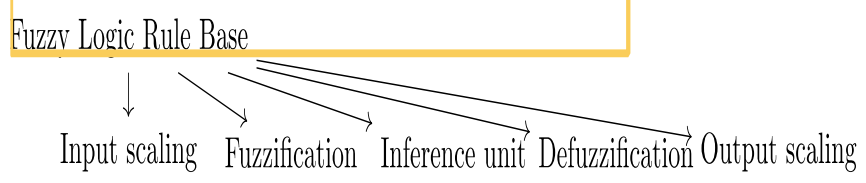

Fig. 1 Fuzzy Logic Control System

Input scaling, fuzzification, inference unit, defuzzification and output scaling components are required to apply fuzzy logic to a real application. Fuzzy set theory permits membership function valued in the interval $[0,1]$. The value 0 is not a member, while the value of 1 indicates being a full member. Values between $(0$, 1) belong to the concept of partial membership. Therefore, a membership function $\mu_{\mathrm{A}}(\mathrm{x})$ is associated with a fuzzy set A such that the function maps every element of universe of discourse $\mathrm{X}$ to the interval $[0,1]$.

The mapping is written as: $\mu_{\mathrm{A}}(\mathrm{x}): \mathrm{X} \rightarrow[0,1]$. In this work, the information coming from the sensors is processed with the fuzzy logic control on the micro-controller of PLC or any other controller.

\section{Results and Discussion}

Traffic signals are traffic control devices used to ensure a regular and safe traffic flow on roads, especially at intersections. The periodic lighting of these illuminated signs at certain times and regulating the traffic flow is called signaling. On the other hand, intersections regulate traffic flow by connecting the intersecting roads of the city. While pre-set traffic light cycle time is used in classic traffic control system, traffic lights and cycle times can be changed at intersections by using proximity sensors with pre-set cycle time. Investigations have been started to calculate signal durations on traffic lights with studies on the control of traffic lights by Webster in 1958. Traffic density at intersections have increased with the increase in the number of private vehicles. Therefore, with the regulation of the traffic flow at intersections, a decrease will be observed in the fuel costs and the gases released from the vehicles to the environment.

In this study, the information coming from the sensors is processed with the fuzzy logic control in the PLC. Input parameters vehicle density of each way of the intersection; output parameters duration of green lights of each way of the intersection were described by Fuzzy logic control in the PLC.

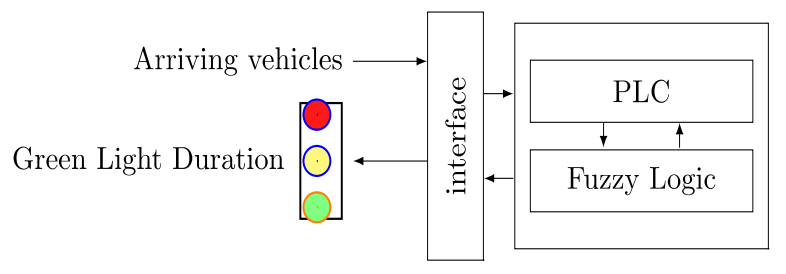

Fig. 2 Parameters of the System

Actual data collected during the day have been used according to observation made at an intersection in Şanlıurfa, the system has been modeled that vehicle density at the intersection is between 0-22 vehicles, the green light duration is between $0-18$ seconds. Three different linguistic variables are defined by 
defuzzification input and output variables coming to the automation system as in the below;

\begin{tabular}{|l|l|l|l|}
\hline \multicolumn{2}{|c|}{$\begin{array}{l}\text { Density of vehicles waiting on } \\
\text { the queue at the intersection }\end{array}$} & \multicolumn{2}{c|}{ Green light duration } \\
\hline Range & $\begin{array}{l}\text { Linguistic } \\
\text { variables }\end{array}$ & $\begin{array}{l}\text { Signal } \\
\text { time }\end{array}$ & $\begin{array}{l}\text { Linguistic } \\
\text { variables }\end{array}$ \\
\hline $0-8$ & $\operatorname{Less}\left(L_{1}\right)$ & $0-5$ & $\operatorname{Short}\left(S_{1}\right)$ \\
\hline $5-13$ & $\operatorname{Medium}\left(L_{2}\right)$ & $4-10$ & $\operatorname{Medium}\left(S_{2}\right)$ \\
\hline $10-22$ & $\operatorname{High}\left(L_{3}\right)$ & $8-18$ & $\operatorname{Long}\left(S_{3}\right)$ \\
\hline
\end{tabular}

Tablo. 1 Linguistic variables

In this study, the vehicle density on the road is considered as input parameter and the green light duration as output parameter by using the triangle membership function. The roads at the intersection are named road-a, road- b, road-c and road-d respectively. The input variable by observing the vehicle density on the roads is introduced to the system as Less (L1) for 0-8 vehicles, Medium (L2) for 5-13 vehicles and High (L3) for 10-22 vehicles. Green light duration the output variable is introduced to the system as Short (S1) for 0-5 second, Medium (S2) for 4-10 second and Long (S3) for 8-18 second. follows;

The membership function for the arriving vehicles is as

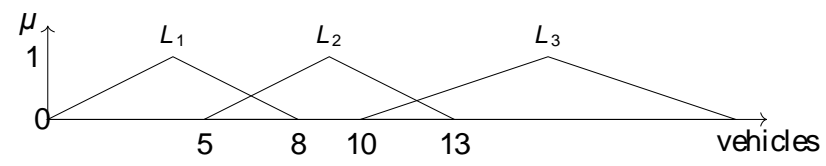

The next figure shows the membership function for the output variable green light duration as follows;

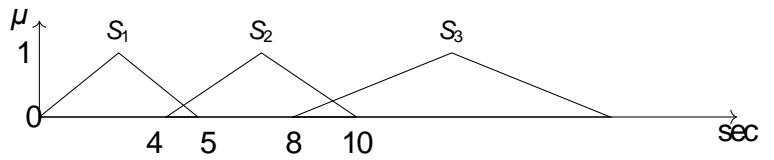

The interface element has been developed with the aid of following figure.

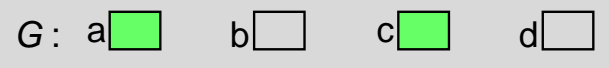

This screen shows which road the green light is on for the moment. Also, the times of the signal lights can be displayed on the PLC.

For the rule based, the road with the highest vehicle density at the intersection will be selected. Then, the green light duration is changed according to the vehicle density of the remaining roads.
1. (road-a=less) \& (road-b=less) \& (road-c=medium) \& (road-d=high) $\Rightarrow($ road-d)

2. (road-a=less) \& (road-b=less) \& (road-c=high) \& (road-d=medium) $\Rightarrow($ road-c)

3. (road-a=less) \& (road-b=medium) \& (road-c=medium) \& (road-d=high) $\Rightarrow$ (road-d)

4. (road-a=medium) \& (road-b=less) \& (road-c=medium) \& (road-d=high) $\Rightarrow($ road-d)

5. (road-a=less) \& (road-b=medium) \& (road-c=high) \& (road-d=less) $\Rightarrow($ road-c)

6. (road-a=medium) \& (road-b=less) \& (road-c=high) \& (road-d=less) $\Rightarrow$ (road-c)

7. (road-a=less) \& (road-b=high) \& (road-c=medium) \& (road-d=less) $\Rightarrow$ (road-b)

8. (road-a=medium) \& (road-b=high) \& (road-c=medium) \& (road-d=less) $\Rightarrow($ road-b)

9. (road-a=less) \& (road-b=high) \& (road-c=less) \& (road-d=medium) $\Rightarrow$ (road-d)

Fig. 3 Rule Base for Road Selection

For 3rd rule in figure 3, when the road-d is in high density at the intersection, road-d will be selected and the green light will be active for this road.

1. (road-a=medium) \& (road-b=less) \& (road-c=medium) \& (road-d=less) $\Rightarrow$ (green light time=decrease)

2. (road-a=high) \& (road-b=less) \& (road-c=less) \& (road-dehigh) $\Rightarrow$ (green light time=decrease)

3. (road-a=high) \& (road-b=high) \& (road-c=less) \& (road-d=less) $\Rightarrow$ (green light time=decrease)

4. (road-a=less) \& (road-b=medium) \& (road-c=less) \& (road-d=medium) $\Rightarrow$ (green light time=decrease)

5. (road-a=medium) \& (road-b=medium) \& (road-c=less) \& (road-deless) $\Rightarrow$ (green light time=decrease)

6. (road-a=less) \& (road-b=less) \& (road-c=less) \& (road-d=high) $\Rightarrow$ (green light time=increase)

7. (road-a=less) \& (road-b=less) \& (road-c=high) \& (road-d=less) $\Rightarrow$ (green light time=increase)

8. (road-a=less) \& (road-b=medium) \& (road-c=less) \& (road-deless) $\Rightarrow$ (green light time=increase)

9. (road-a=less) \& (road-b=less) \& (road-c=less) \& (road-d=less $) \Rightarrow$ (green light time=increase)

Fig. 4 Rule Base for Green Light Duration

In order to be able to decide on the green light duration after the path is selected, the green light duration for road-d will be increased in the case that the road-d is at high intensity in the 6rd rule in figure 4.

\section{Conclusions and Recommendations}

In this study, we present the philosophy of fuzzy logic and show its availability with automation in traffic signalization system. It is observed from the graph below that Fuzzy logic method is more efficient both in terms of economy and time when traffic signaling control is performed with fuzzy logic and classical methods. with the regulation of the traffic flow at intersections, a decrease will be observed in the queue length at the intersection and the harmful gases released from the vehicles to the environment.

\section{Acknowledge}

In that paper, we observed that Fuzzy logic method is more efficient in terms of economy, time and environment when traffic signaling control is performed with fuzzy logic and classical methods.

\section{References}

[1] L. A. Zadeh, "Fuzzy Sets", Intl J. Information Control 8: 338-353ü, 1965.

[2] E. H. Mamdani and S. Assilion, "An Experiment in Linguistic Synthesis With a Fuzzy Logic Controller", Intl J. Man-Machine Stud 7:1-13, 1974.

[3] L. P. Holmblad and J. J. Ostergaard J, Control of Cement Kiln by Fuzzy Logic, Gupta M. M, Sarchez E, Fuzzy Information and Decision Processes, North Holland, pp. 389-399, 1982. 
[4] S. Chiu and S. Chand, "Adaptive Traffic Signal Control Using Fuzzy Logic", Proceedings of the Intelligent Vehicles '92 Symposium, 98-107, 1992.

[5] E. H. Mamdani, "Application of fuzzy algorithms for control of simple dynamic plant", Proc. IEEE, 121(12), 1585-1588, 1974.

[6] T. Munakata and Y. Jani, "Fuzyy systems: an overview, Communications of the ACM, 37(3), 69-76, 1994.

[7] L. A. Zadeh, G. J. Klir and B. Yuan, "Fuzzy sets, fuzzy logic, and fuzzy systems: selected papers", World Scientific, 1996.

[8] U. Ozkaya, and L. Seyfi,“A novel fuzzy logic model for intelligent traffic systems". Electronics World, 122(1960), 36-39, 2016.

[9] A. P. Akgungor and A. G. R. Bullen, Analytical delay models for signalized intersections, 69th ITE Annual Meeting, Nevada, USA, 1999.

[10] M. Collotta, L. L. Bello, and G. Pau, "A novel approach for dynamic traffic lights management based on Wireless Sensor Networks and multiple fuzzy logic controllers", Expert Systems with Applications, 42 (13), 5403-5415, 2015. 